York 1988), p. 194 reports that they exchanged charges of homosexuality and mistreatment of wives. According to Kenneth S. Lynn, Hemingway (New York 1987), p.417, Hemingway heard McAlmond planned to write unpleasant things about him in his reminiscences (returning Hemingway's uncomplimentary portrayal of McAlmond in Death in the Afternoon) and beat him up without waiting for confirmation or denial.

10. The match took place on Sunday, 27 Oct. 1935 in New York before a crowd of 32,000 including the Postmaster-General James Farley. The New York Times, 28 Oct. 1935 and 3 Nov. 1935 reports the game, noting that Chicago had won the game from behind (14-13) through a strong running attack and a wide-spread passing formation, particularly a forward pass from Ike Peterson to Bill Smith which gained 46 yards and a touchdown. Perhaps, that was the play Callaghan meant but the columnists do not mention the strategy in Callaghan's terms.

11. Letter, Morley Callaghan to Dink Carroll, undated (accompanying envelope postmarked 2 Dec. 1935), MG 4151, c.4, file: "Letters from Morley Callaghan".

12. Letter, Loretto Callaghan to Margaret Carroll, 18 March 1949, MG 4151, c.4, File: "Letters from L. Callaghan". The Montreal novel was The Loved and the Lost (1951).

13. MG 4151, c.1, untitled.

14. Archives MATCH Volunteer Elizabeth Shapiro, who helped arrange and describe the Carroll Papers, undertook the daunting task of identifying and piecing together the often-disordered works of fiction.

15. MG $4151, \mathrm{c}, 1$, untitled story.

16. MG 4151, c. 1 , file 4 : drafts for an untitled novel(?)

17. MG 4151, c. 1, untitled.

18. Ernest Hemingway, The Sun Also Rises (1926), chapter 3: "Brett was damned good looking. She wore a slipover jersey sweater and a tweed skirt, and her hair was brushed back like a boy's. She started all that."

\title{
History of the Polish Institute Library in Montreal
}

\author{
By Hanna M. Pappius, Ph.D. \\ Director of the Library, Polish Institute
}

In 1943 a group of Polish academics who had found refuge in Montreal, together with a number of their Canadian colleagues and with the enthusiastic support of the eminent Polish historian Professor Oskar Halencki, then at Columbia University, established the Canadian Section of the Polish Institute of Arts and Sciences in America. One of the first decisions of the new section was to start a library. Subsequently, the Canadian Section became the Polish Institute of Arts and Sciences in Canada (PIASC). As PIASC approaches its 50th anniversary the Polish Library at McGill University can be considered as its most important and enduring achievement.

In 1943 the library consisted of a small collection of books for the use of members of PIASC. By the end of World War II its character had changed with a readership extending to the whole Polish community in Montreal and beyond, although it continued to be run exclusively by volunteers. It was only in 1982 that PIASC obtained a grant from the City of Montreal for the services of a professional librarian. This was a crucial development for the Polish Library as its operation without professional staff was begining to seriously impair its growth. In the last decade the Polish Library has steadily increased its holdings and its activities. 


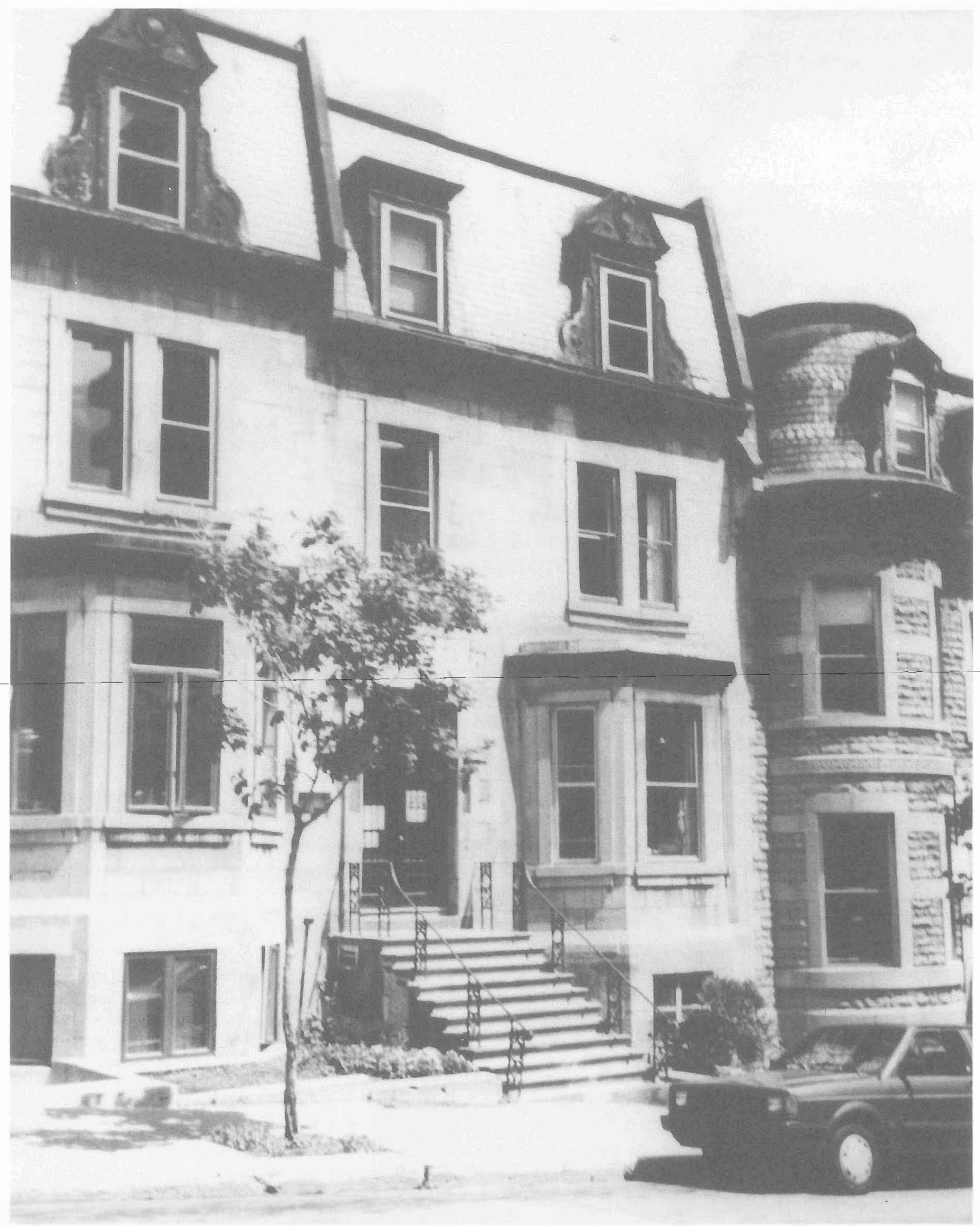

The Polish Institute Library 


\section{Notes and Comments}

From its inception the Polish Library was a special concern of Mrs. Wanda Stachiewicz its founder, for many years its Director and to this day its Curator. While over the years many individuals have contributed to the growth of the library under the leadership of Mrs. Stachiewicz, it is she who must be credited with its development over the decades into an important Polish cultural institution in North America. In appreciation of her invaluable contributions, at the annual meeting in 1984, members of PIASC voted to name the library The Wanda Stachiewicz Polish Library.

\section{Polish Library Holdings}

The Polish Library collections consist primarily of the humanities divided (approximately) between literature $(35 \%)$, history and social studies $(35 \%)$, arts (15\%), religion $(5 \%)$, and children's literature (10\%). The majority of the books are in Polish, but both English and French publications on Polish subjects or by Polish authors are included.

The total number of items in our inventory book, which lists acquisitions since the Library's inception, is 40,000 as of July 1992. This, however, includes duplicates and does not account for losses in the intervening years. The actual total of books currently in the library is estimated as between $30,000-35,000$. About 1,000 books are now added to the holdings each year, partly by purchase, partly from private donations and as gifts from various publishers.

About 15,000 of the books in the Polish Library can be considered as part of our "academic" collection, as defined by our agreement with the McGill University Libraries, and these are included in the MUSE on-line catalogue. The remaining 20,000 books are translations into Polish from other languages and material for our popular lending library. The Polish Library also contains several hundred periodical titles and a valuable collection of old maps and graphics.

\section{Activities of the Polish Library}

The Polish Library is a reference library for staff and students of McGill University and other Montreal universities. Items already listed in the McGill on-line catalogue and hence in the UTLAS database are available to users of most university libraies in Canada and some in the United States.

The Polish Library in Montreal is also a community lending library open to interested individuals on payment of a modest fee. Currently the library has over 1,300 registered regular users who in the academic year 1991-92 borrowed 16,500 books. The library operates a reading room with a large number of periodicals and newspapers published both in Poland and in North America. The Polish Library receives daily from Warsaw via electronic mail a bulletin of lastest events in Poland, called DONOSY.

\section{Support}

From the beginning of its existance PIASC and its library have found their home at McGill. After a modest beginning in a single room, the Polish Library is now housed in a University building on Peel Street. Without this very substantial support by McGill, the Polish Library could not have developed and prospered as it has. The Polish Library is a unique insitution in that it is an independent library owned and operated by a Polish-Canadian cultural organization but closely associated with a prestigious North American university.

While the financial situation of the Polish Library has sometimes been difficult, in recent years the support of the Polish community in Canada has made it possible for the Library not only to maintain the level of its services but also to grow substantially and initiate its modernization by the computerization of its catalogue. Currently the 
Library's operating funds come from several sources. Since 1982 the Library receives an annual grant from the City of Montreal towards the salary of a professional librarian. During the last ten years the Library has received annual support from the Polish Cultural Foundation of Quebec and the Millenium Fund of Toronto. Finally, since 1988 the Library has organized an annual public appeal for funds, directed to the Polish community in Canada.

\section{Personnel}

Since $1985 \mathrm{Mr}$. Stefan Wladysiuk, M.L.S., graduate in Library Science of University of Gdansk, has been the Polish Library Librarian. He is responsible for all aspects of library activities. In $1988 \mathrm{Ms}$. Sophie Bogdanski, M.L.S., graduate in Library Science from University of Toronto joined the library staff as Librarian Cataloguer.

From its inception the Polish Library has relied on the work of a dedicated group of volunteers. At present, under the guidance of the Librarian, 18 persons are responsible for the operation of the lending library, internal online cataloguing of acquisitions, binding and general maintenance of the holdings.

Currently the position of the Director of the Polish Library is held by Dr. Hanna M. Pappius, Ph. D., Professor in the Department of Neurology and Neurosurgery, Montreal Neurological Institute, McGill University and, since 1988, Vice-President of PIASC.

\section{Modernization of the Polish Library}

In 1989 a decision was made to modernize the Polish Library. Discussions were initiated with Dr. Eric Ormsby, Director of McGill University Libraries to have the Polish Library holdings incorporated into the McGill on-line catalogue in order to make them more widely known and used, and to connect the Polish Library to the MUSE system. A 1989 review of the Polish Library holdings by McGill Library representatives showed that approximately 13,000 volumes of monographs (history of Poland 4,500; Polish literature 2,400; social sciences 1,700; biography 1,500, fine arts 1,200; religion and philosophy 950; reference 1,000) represented a "valuable, unique collection of material relating to one country" whose "growth and preservation was very much of interest." Subsequently, it was agreed that material meeting McGill University criteria would be incorporated in the MUSE on-line catalogue with the Polish Institute Library as the "location." Briefly, it was decided that books on Polish history and culture in the widest sense and classics of Polish literature would all be included in MUSE, while translations from other languages into Polish and material obviously suitable only for the general public would be excluded.

The decision to include the Polish Library material, previously catalogued according to the Dewey classification, in the MUSE catalogue necessitated its recataloguing according to the Library of Congress classification into UTLAS database in use at McGill. It was agreed that this would be done in the Technical Services Department of McGill Libraries by a cataloguer hired by the Polish Library.

As a part of the modernization process it was decided that Polish Library's internal catalogue would also be computerized.

Since September 1989 all new "academic" acquisitions have been catalogued by Ms. Sophie Bogdanski from Technical Services at McGill with some help from a part-time library technician and all acquisitions have been incorporated into our internal computerized catalogue by two volunteers under the supervision of the librarian. During the intervening three years the mechanisms for the cataloguing of the Polish Library material were developed according to our rather unique needs and fine-tuned for efficient operation. They were shown to be workable and can now be considered as fully operative. The Polish Library is totally committed to re-cataloguing its entire "academic" collection and funds are being sought currently for this purpose. 


\section{Notes and Comments}

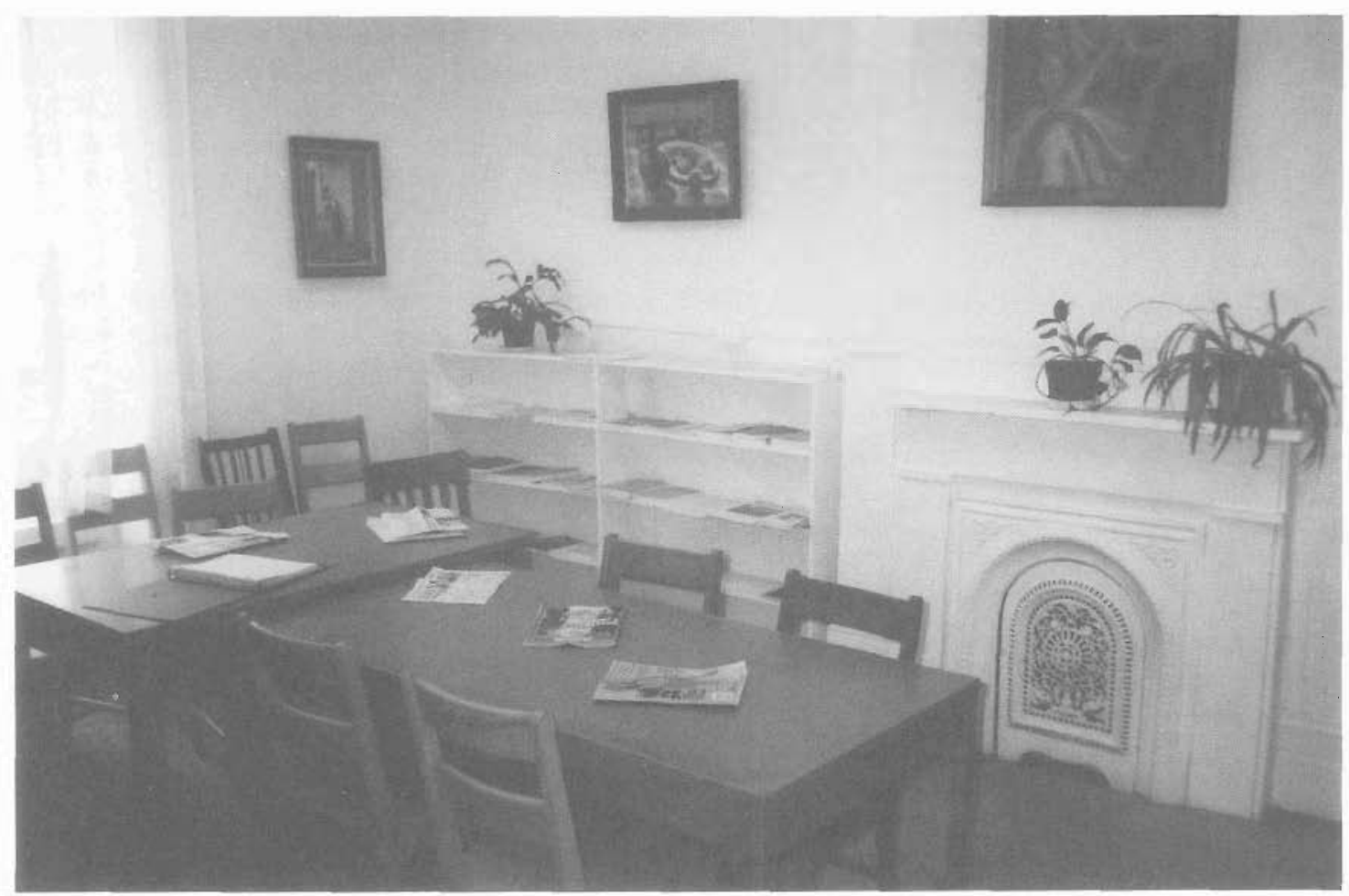

The Reading Room of the Polish Institute Library.

\section{Highlights the Polisin ibridy Collection}

The nost importar: sems of the Poilst Library collection are found in ts eference section of approximate y 1,500 olumes. Of particuiar interes are The Seographical Dictionary of the rolish Kingdom and other Slavic

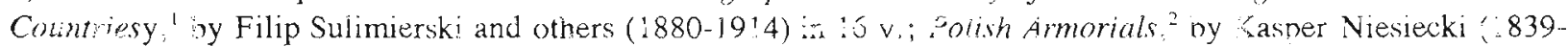
1846) in $10 \mathrm{v}$, and another ${ }^{3}$ by Adam Boniecki (1899-1913) in i6 v.; The Polish Bibliouraphy started by . Baroi Estreicher in : 872 and The Polish Bibliographical Dictionary beginning with 935 voi. 2 . The Polish Library also as numerous statistical annuals and 'anguage dictionaries.

An unusua item in our coliection is a facsimile of the manuscript popularly krown as the Cociex of 3ehem, 505 . The manuscrip contains the privileges and statutes of the city of Cracow. The twenty-seven ar:onymous miniatures, insnired by Flemish and south German art, are an integrai part of the manuscript. These depict Christ on the Cross, the coat of arms of the cify of Cracow, the emblems of certain guilds, and above ail, scenes from the daily iives of merchanis and artisans. The Codex of Behem, with its miniatures, is a unzuse source of history of municipa: law, economics, culture and customs of a 16th century Polish city. The original belongs to the Jagiellonian Library of Cracow.

Sources pertaining to Polish history and jursidiction in the Polish Library deserve special aftention. The Polish Library owns an English edition of the 3rd of May Constitution of 1791 and a four-volume "Annass of Law" passeri by the Duchy of Warsaw (1807-1815) published in both Polish and French. There is also a 6-volume "Annais of aw" of the Kingdom of Poland, as the country was known between 1815-1918 under the Russian occupation. It 


\section{Notes and Comments}

is $s_{i}$ interest that these ukases (decrees) were published in Polish and Russian. Finally, the Polish Library has copies of the two constitutions of Poland and the "Annals of Law" for the period between World Wars I and II, as weii as a number of commentaries on Polish consitutional anu legal matters. All these provide a valuable and incept materia: fo: research on the history of the Poish par-iamentary system that had been in existence in one form or other for neariy 500 years.

Tiriag the post-war period when writing in Poland was under strict censorship, the Polish Library developed a unique co:lectionn of materials dea:ing with Poish history and culture published clandestinely in Poland and openly in the West.

\section{Sonciusior}

The Poiish Library at McGili owes its continuing development to the generosity of the enlightened members of the Polish-Canadian community, to efforts of its devoted volunteers and last, but not least, to the support of McGill University.

During almost half a century the library contributed to preserving independent Polish thought and culture. With the recent political changes in Central Europe it is possible to establish uncensored contacts with academic institutions in Poland, where currently western advances in library technology are being implemented. This will ai-ow the Polisii idibrary to take advantage of a variety of resources available in Poland, for example on-line access to the Polish National Bibliography and catalogues of various university libraries. These contacts with sources in $D_{0}$ and wi i make them more accessible to interested users in Canada. At the same time, researchers in Poland wil! be able to make full use of the unique holdings of the Polish Library. Thus the future of the Polish Library is brighs.

The Polish iibrary is located at 3479 Peel Street, Montreal, Quebec, H3A 1W7. Telephone: [514] 398-6978. Fax: [514] 398-8184. E-mail: CXSW@MUSICA.McGILL.CA

\section{Notes}

1. Slownik Geograficzny Krolestwa Polskiego i Innych Krajow Slowianskich (Geographical Dictionary of the Polish Kingdom and other Slavic Countries), by Filip Sulimierski and others 1880-1914 (facsimile reprint) in sixteen volumes.

2. Herbarz Polski (Polish Armorials), by Kasper Niesiecki, 1839-1846 (reprint) in ten volumes.

3. Herbarz Polski by Adam Boniecki, 1899-1913 (reprint) in sixteen volumes.

4. Bibliografica Polska (Polish Bibliography) started by Karol Estreicher in 1872.

5. Polski Slownik Biograficzny (Polish Biographical Dictionary) begun in 1935. 